\section{Jumping the greenhouse gun?}

SIR-I do not know from what source John Maddox is quoting me in your issue of $7 \mathrm{July}^{1}$, nor do I admit to jumping any gun. He believes I should know better. I believe I do know better.

Assuming that he is referring to my address to the World Conference on the Changing Atmosphere on 27 June 1988, in Toronto, then I asserted nothing, but argued as follows:

And can we detect the greenhouse effect in existing climatic records? (No approach) has yet given an unequivocal answer. But painstaking examination of the global surface and sea temperature records over the past century has begun to yield good results. Analysis by Jones et al. (1986), for example, shows a global rise of temperature between 1860 and 1980 of approximately 0.5 to $0.6^{\circ} \mathrm{C}$ (ref. 2). Villach 1985 (a WMO/UNEP/ICSU assessment) estimates that the greenhouse effect over the past century should have raised temperatures between 0.3 and $0.7^{\circ} \mathrm{C}$ (ref. 3). The observed signal is thus compatible with the predicted greenhouse warming .... Firmer answers to this question will have to wait a few years. But I should like to express the personal view, based on long experience rather than personal research, that we are indeed witnessing the beginnings of the process, and that the delegates did not come to the conference to chase a will-o'-the-wisp".

I added, in a verbal aside, that I agreed with remarks attributed the previous week to J.E. Hansen, before a US congressional committee, that "it is time to stop waffling so much and say that the greenhouse effect is here" ${ }^{5 "}$. Of course I did not testify myself.

Until a short while ago, my own position (as chairman of the WMO/UNEP/ ICSU Advisory Group on the Greenhouse Cases, inter alia) was much like Maddox's: that the evidence was too equivocal to do more than give a yellow alert to governments (for whom, incidentally, the Toronto Conference was run). I was an announced wait-and-see conservative.

It was the paper by Jones et al. ${ }^{2}$ published in Nature that began to sway me towards the above position. This was reinforced by an update, also in Nature, establishing that 1987 was the warmest year on record, and that the 1980 s clearly show a resumed upward trend ${ }^{6}$. Overall, there is an unmistakable quasilinear upward trend over the entire period 1860 1987, on which large interannual and interdecadal fluctuations are superposed, as Maddox indicates. This is true in both hemispheres.

Obviously this is no proof that the greenhouse effect is at work, nor will there be any such proof that satisfies everyone, hence my words "personal view" not committing either of the two bodies I chair. But the trend fits what theory predicts, in the shape of several major general circulation models that have tested the hypothesis, and come up with the figures I quoted. All the difficulties and uncertainties cited by Maddox are, of course, wellknown to those of us who play this game.

As a scientist, I will hence confine myself to saying that the best available explanation for the upward trend of surface temperature is the build-up of the greenhouse gases, and the response of the atmosphere to the change in optical behaviour. As an adviser to my government I have to be more explicit. I can and do tell them that they should base their environmental planning on the assumption that the greenhouse warming will continue and accelerate. There will always be conservatives who decline to go this far. At the age of 69 I can no longer afford to be conservative.

F. KENNETH HARE (Chairman)

Climatic Planning Board of Canada, Toronto, Ontario, Canada

1. Nature 334, 9 (1988)

2. Jones, P.D. et al. Nature 322, 430-434 (1986)

3. Villach 1985, Report... on the Assessment of Carbon Dioxide . . . in Climatic Variations and Associated Impacts, WMO-961, 75pp. (1986).

4. Hare, F.K. in Report of the World Conference on the Changing Atmosphere, Toronto, 27-30 June 1988 (in the press).

. Highfield R Observer, 28 June 1988.

6. Jones, P.D. et al. Nature 332,790 (1988)

Sir-In my book Pesticides and Pollution, published in 1967, I said: "So far most scientists have thought that $\mathrm{CO}_{2}$ pollution was of little importance; it now seems possible that it may cause greater changes to the world than any other man-made factor in our environment. On the other hand, this may be a completely false alarm".

Twenty years ago, most members of the 'scientific establishment' thought it was a false alarm. It was generally believed that temperature fluctuations such as had occurred over the past few thousands of years would be much greater than any induced by man-made atmospheric changes.

Today the situation is quite different. There is general agreement that some effect will be manifested if greenhouse gases, particularly $\mathrm{CO}_{2}$ and methane, continue to increase. And, as John Maddox (Nature 334, 9; 1988) concludes, governments must decide what to do when the effect is palpable. But we still do not know when this will happen, and what the magnitude of the effect will be.

I see in the press that there is now a worry that the Thames barrier will be insufficiently high to cope. Some years ago, when this work was nearing completion, I visited the site with the Parliamentary and Scientific Committee. After our inspection, we had a question-and-answer session. I asked whether the possible effects of a rise of ocean levels due to greenhouse gases had been taken into consideration in planning the barrier. I was assured that it had. We now learn that it had not, which should be a lesson to our planners and civil engineers.

38 Warkworth Street,

Kenneth Mellanby

Cambridge CB1 1EG, UK

\section{Magic results}

SIR-I was intrigued by your use of a professional magician in the inquiry into the conduct of experiments reported by Davenas et al. (Nature 333, 816-818; 1988), indicating biological activity of antibody solutions containing no antibody molecules. It is true that the results reported contradict accepted ideas, and scientists require much more persuading before believing them. But error and even fraud are known to exist in other much more conventional fields. This is especially true in medical research and biology, where there are many pressures. Even in physics, however, the desire to win the Nobel prize may lead to doubtful interpretations being suggested, as now appears to be the case for the claimed 'fifth force'. I suggest therefore that professional magicians be employed to verify all experimental results reported in Nature. This would not only lead to equal treatment of different scientists but would also give regular employment to magicians, at present dependent on the economics of show business.

Michael Friedjung

CNRS Institut d'Astrophysique,

98 Bis, Boulevard Arago,

75014 Paris,

France

\section{Men only?}

SIR-The review by Stuart Sutherland of A Passion for Science (Nature 334, 112; 1988) emphasizes that scientists are tempted to steal colleagues' wives and pinch au pairs' bottoms. As well as musing over the changing colour of women's stockings (stockings?), he could perhaps have assessed whether a suitable subtitle might be The Joy of Sexism.

Department of Obstetrics and

Gynaecology,

University of Leeds,

' $D$ ' Floor, Clarendon Wing,

Belmont Grove,

Leeds LS2 9NS, UK 